\title{
Efeitos ototóxicos da exposição ao monóxido de carbono: uma revisão****
}

\section{Ototoxic effects of carbon monoxide exposure: a review}

\author{
Adriana Lacerda* (adriana.lacerda@umontreal.ca) \\ Tony Leroux** \\ Thais Morata***
}

*Fonoaudióloga. Doutoranda no Programa de Sciences BiomédicalesAudiologie pela Université de Montréal - Canadá. Professora Adjunta do Curso de Fonoaudiologia da Universidade Tuiuti do Paraná.

**Audiologista. Doutor em Psicologia pela Carleton University, Ottawa Canadá. Professor Adjunto da École D'Orthophonie et D'Audiologie da Université de Montréal - Canadá.

***Fonoaudióloga. Pós-Doutora pelo National Institute for Workink Life (NIWL), Suécia. Professora do Programa de Mestrado em Distúrbios da Comunicação da Universidade Tuiuti do Paraná, Curitiba, Brasil. Pesquisadora do National Institute for Occupational Safety and Health, Cincinnati, EUA.

****Trabalho Realizado na Université de Montreal.

Artigo de Revisão de Literatura

Artigo Submetido a Avaliação por Pares

Conflito de Interesse: não

Recebido em 16.02.2005. Revisado em 17.04.2005; 26.07.2005; 9.11.2005

Aceito para Publicação em 9.11.2005.

\begin{abstract}
Background: ototoxic effects of carbon monoxide exposure: a review. Aim: to analyze the literature on hearing and Carbon Monoxide (CO). Methods: to describe the physical properties, the absorption, distribution and metabolism of $\mathrm{CO}$, as well as its origin, production, sources and the international standards for occupational exposure. Several studies about the effects of $\mathrm{CO}$ exposure to the auditory system of humans and experimental animals were discussed. The main economic sectors where the combined exposure to noise and $\mathrm{CO}$ takes place were identified. A description of the basic $\mathrm{CO}$ toxic mechanisms that are able to raise occupational noise-induced hearing loss was given. Conclusion: the review of the literature indicated the following: 1. Examples of $\mathrm{CO}$ exposure sources include air pollution, smoking and second-hand smoking, and occupational exposures. 2. CO's main toxic mechanism can lead to hypoxia due to the conversion of oxyhemoglobin to carboxyhemoglobin. 3. Rats have been the most used experimental animals in $\mathrm{CO}$ auditory effects studies, this group of studies has demonstrated the combined effects of acute exposure to $\mathrm{CO}$ and noise. 4. Studies about the negative effects of $\mathrm{CO}$ exposure over the human auditory system were mainly carried out after acute exposures to $\mathrm{CO}$. These studies did not control or report exposure to noise as a contributor to the observed hearing deficits. Currently the available evidence indicates the need for further research on the effects of $\mathrm{CO}$ exposure to the auditory system, alone or in combination with noise.
\end{abstract}

Key Words: Occupational Health; Toxicity; Hearing; Chemical Compounds; Drug Synergism.

\section{Resumo}

Tema: efeitos ototóxicos da exposição ao monóxido de carbono: uma Revisão. Objetivo: analisar a literatura sobre audição e o monóxido de carbono (CO). Método: descrever as propriedades físicas, a absorção, a distribuição e o metabolismo do $\mathrm{CO}$, bem como a sua origem, sua produção, suas fontes e os seus limites internacionais de exposição ocupacional. Foram discutidos vários estudos sobre os efeitos do CO no sistema auditivo animal e humano. Finalmente, foram identificados os principais setores onde podemos encontrar a exposição combinada ruído e $\mathrm{CO}$ e descrevermos os mecanismos básicos de ação do CO que poderão potencializar a perda auditiva induzida por ruído. Conclusão: a revisão de literatura indicou que: 1. A poluição atmosférica, o fumo passivo, a exposição ocupacional, e o tabagismo ativo, são exemplos de fontes de exposição ao CO. 2. A ação tóxica principal do CO resulta em anoxia provocada pela conversão da oxihemoglobina em carboxihemoglobina. 3. Os estudos animais sobre a exposição combinada ao ruído e ao $\mathrm{CO}$ foram realizados em sua grande maioria com ratos e o conjunto destes estudos demonstraram os efeitos da exposição aguda e simultanêa ao CO e ao ruído. 4. Os estudos relatando a nocividade da exposição ao CO sobre o sistema auditivo humano foram realizados, na grande maioria, seguidos de uma exposição aguda ao CO. A exposição ao ruído não foi relatada ou controlada como um fator relacionado com os problemas auditivos observados. A evidência existente até o momento indica a necessidade do desenvolvimento de pesquisas sobre os efeitos auditivos da exposição a CO, com e sem exposição ao ruído.

Palavras-Chave: Saúde Ocupacional; Audição; Compostos Químicos; Sinergismo de Drogas. 


\section{Introduction}

Occupational hearing loss constitutes an important health problem in our society. In the past decades, scientific publications have discussed the numerous harmful consequences of noise exposure on hearing and on health in general. Besides the presence of noise in the workplace, other environmental agents combined with noise present a potential hearing risk, even under conditions of exposure to relatively low noise levels.

Many chemical agents were identified as being potentially toxic in studies utilizing animal models and/or through epidemiological studies in the workplace. These agents include organic solvents, chemical asphyxiants, metals and ototoxic drugs.

The risk of hearing loss in the presence of moderate noise exposure associated with the presence of asphyxiants was evaluated mainly using animal models. These studies demonstrate increased noise-induced hearing loss (NIHL) when rats were exposed simultaneously to carbon monoxide (CO) and noise levels that by themselves did not produce any change to the hearing threshold.

The objective of this article is to present $\mathrm{CO}$ to the reader, as well as its physical properties, production and sources, the different occupational exposure limits, and its effects over the human and animal auditory systems; to identify the sectors where we can find the combined exposure to noise and $\mathrm{CO}$, and describe the basic mechanisms of action of $\mathrm{CO}$ that could potentiate NIHL, one of the most frequent types of hearing loss in the work place.

\section{Carbon Monoxide}

Physical properties, absorption, distribution, and metabolism

$\mathrm{CO}$ is a member of the chemical asphyxiant family, and is a dangerous gas. It has no color, no smell, no taste, and irritates the skin. It can knock someone unconscious or even kill them within minutes. It is called the silent assassin, and is produced by the incomplete combustion of organic materials, like coal, wood, paper, oil, gas, and gasoline. (WHO 1979; NIOSH 1981; IPCS 1999; Penney, 2000).

According to Lauwerys (1990), CO has affinity to the hemoglobin contained in red blood cells that transport oxygen $\left(\mathrm{O}_{2}\right)$ to the organ tissue of all the body's organs.
The toxicity of $\mathrm{CO}$ on human is explained when $\mathrm{CO}$ enters in competition with $\mathrm{O}_{2}$ through the hemoglobin. The principal toxic action of $\mathrm{CO}$ results in anoxia, which is provoked by the conversion of oxyhemoglobin into carboxyhemoglobin $(\mathrm{COHb})$. The affinity of hemoglobin towards CO is 240 times stronger than its affinity towards $\mathrm{O}_{2}$ (IPCS, 1999; Laliberte, 2001).

The toxic action would result equally in the reduction of the liberation of the $\mathrm{O}_{2}$ fixed upon the hemoglobin, diminishing the quantity of available $\mathrm{O}_{2}$ to the level of the tissues, from the link of the $\mathrm{CO}$ with the myoglobin from the myo-cardiac and skeletal muscular cells, and also the link of the $\mathrm{CO}$ with cytochromes, which provokes an inhibition of the Krebs cycle (IPCS, 1999; Laliberte, 2001).

The existence of a chronic intoxication from $\mathrm{CO}$ resulting from prolonged exposure to low concentrations can cause toxic effects such as insomnia, migraines, fatigue, diminished physical capabilities, dizziness, vertigo, nausea, vomiting, visual disturbances, hearing disorders, Parkinson's Disease, cardiac ischemia, heart disease and arteriosclerosis (IPCS, 1999; Penney, 2000; Martins et al., 2002; Bakonyi et al., 2004; Freitas et al., 2004).

Origins, production, and sources

Approximately $60 \%$ of $\mathrm{CO}$ present in the troposphere originates from human activities through the process of incomplete combustion of organic materials such as coal, wood, paper, oils, gas, gasoline, and others.

Recent statistics about CO concentration relate that its background level is on average 50 to 120 parts per million (ppm) in the environment. The amounts are higher in the northern hemisphere than in the southern hemisphere and the level fluctuates equally depending on the seasons. The amount is lower in the summer (IPCS, 1999).

The atmospheric pollution, second hand smoke, occupational exposure, and smoking, are examples of sources of $\mathrm{CO}$ exposure. Studies about human exposure demonstrate that gas from vehicular exhaust is one of the most frequent sources of high $\mathrm{CO}$ concentration. In particular, they show that inside a car the average CO concentration is between 9 and 25 ppm.

A study done on populations that live in high traffic areas showed that the CO concentrations vary in extreme proportions and the exposure can get to be more than $35 \mathrm{ppm}$. (IPCS, 1999). A study 
by Corriveau (1980) in Montreal (Canada) demonstrates $\mathrm{CO}$ concentrations of $40 \mathrm{ppm}$ in the center of town. In the city of São Paulo (Brazil) the heavy automobiles and trucks are responsible for the emission of 2.065 tons of carbon monoxide annually (Cetesb, 1991).

Martins et al. (2002) investigated the effects and death rate from pneumonia and colds in the elderly caused by atmospheric pollution between 1996 and 1998, by collecting data about the daily levels of particulates (PM10), carbon monoxide (CO), sulfur dioxide $\left(\mathrm{SO}_{2}\right)$, nitrogen dioxide $\left(\mathrm{NO}_{2}\right)$, and ozone $\left(\mathrm{O}_{3}\right)$ in the Companhia de Tecnologia de Saneamento Ambiental (Cetesb) from the city of São Paulo (Brazil). The results revealed that in 1996, CO exceeded the limit for air quality 10 times, and in 1998, the CO exceeded it once.

The work place constitutes an important environment when it comes to $\mathrm{CO}$ exposure because it is one of the most abundant pollutants in the air, and is present with noise in many work places. According to the (IRSST -Institut RobertSauvŽ de Recherche en SantŽ et en SecuritŽ au Travail), approximately 500 cases of intoxication by $\mathrm{CO}$ are identified each year in Quebec (Canada). In addition another third (37\%) resulted from incidents that occurred in the work place. (IRSST, 2003).

The exposure to CO notably concerns workers in the steel and paper industries (Koskela, 1994; Koskela, 2000), in civil construction (Kamei and Yanagisawa, 1997; Baril and Beaudry, 2001; Schneider, 2002), the automotive industries (Liou, 1994) and the oil refineries (Makashima, 1988). Individuals who work near coal ovens are equally at risk (Hetu et al., 1987; Makashima, 1988).

Firemen are frequently exposed to $\mathrm{CO}$ and noise at the same time (Treitman et al., 1980; Lees, 1995; Melius, 2001; Fechter, 2002), as are car mechanics (Cloutier and Goudreau, 1993; Goudreau et al., 1995), traffic police and parking lot attendants (Wickramatillake et al., 1998; IPCS, 1999), bus drivers, truck drivers and taxi drivers (Steenland, 1996; Morley et al., 1999; Fechter, 2002), motor sport athletes (Walker et al., 2001), service stations workers (Kamei and Yanagisawa, 1997; Herbert et al., 2001), workers that work with forklifts, (Millette, 1992), industrial cooks, and/or employees in nightclubs (Penney and Howley, 1989, Laranjeira et al., 2000; Silva, 2000).
Occupational exposure limits

The recommended limits of $\mathrm{CO}$ concentration in the workplace differ from country to country. In the USA, the level proposed by NIOSH (2004) is $35 \mathrm{ppm}$ for an eight-hour workday and $200 \mathrm{ppm}$ for 15 minutes, which is the maximum level. For OSHA (Occupational Safety and Health Administration, 1991) the permitted concentration is $50 \mathrm{ppm}$ for an eight-hour workday (EH-64, 1999). In Canada they follow the limits recommended by NIOSH. In Brazil, law NR-7 (1998) establishes the parameters for biological control of the exposure to some chemical agents, and the $\mathrm{CO}$ concentration limit is $39 \mathrm{ppm}$ per eight-hour workday. Besides the existence of these regulations, $\mathrm{CO}$ concentrations found in the workplace can exceed the permitted limits. For example, in a study by Goudreau et al. (1992), $46 \%$ of the car mechanics in Montreal (Canada) exceeded the dose limit of $\mathrm{CO}$ concentration, which is $35 \mathrm{ppm}$. In another study by the Ministry of Labor, FUNDACENTRO, the CO concentrations present in shopping mall and commercial building parking lots in Rio de Janeiro exceed the dose limit of CO concentration, which is $39 \mathrm{ppm}$ (Fonseca, 2003).

The effects of $\mathrm{CO}$ on the auditory system of experimental animals

The majority of studies about the combined exposure to $\mathrm{CO}$ and noise were done on rats. This species demonstrates a much higher resistance to CO intoxication than observed on humans. In rats, a lethal dose for a 30-minute exposure is $5000 \mathrm{ppm}$; in humans the lethal dose is $1500 \mathrm{ppm}$ (Rao and Fechter, 2000).

Taking into consideration the difference in sensibility to the effects of CO observed in rats, Fechter et al. (2000a) suggested a threshold limit of $22 \mathrm{ppm}$ for occupational exposure. Until now this suggested concentration has not been tested on humans.

Doctor Fechter's team is one of the most renowned international groups interested in the effects of combined exposure of $\mathrm{CO}$ and noise. Several of their studies refer to the effects of acute exposure and simultaneous exposure to both agents. 
The results of the research on the toxic action of $\mathrm{CO}$ on the auditory system tend to show that $\mathrm{CO}$ can have a direct effect on the cochlear metabolism. Also, different biochemical and electrochemical components do not seem to be affected in the same manner. Their results demonstrate effects on the compound action potential (CAP) generated by the auditory nerve fibers that are more relevant in comparison to the effects on the endocochlear potential supported by the stria vascularis and the effects of the potential of cochlear microphonic (CM) generated mainly by the outer hair cells (OHC) (Fechter et al., 1987; Tawackoli et al,. 2001).

The suggested metabolic mechanisms to explain the potentiation of $\mathrm{CO}$ on the effects of noise were:

1. The metabolic exhaustion of succinate dehydrogenase, enzymes of the Krebs cycle (breathing) of the sensory cells, particularly the OHC (Chen and Fechter, 1999; Chen et al., 2000; Fechter et al., 2000a), and the marginal cells of the stria vascularis (Chen and Fechter, 1999).

2. The excitotoxicity related to an increased extracellular glutamate concentration and increased calcium influx, which in the cochlea involves afferent neurons of the auditory nerve in particular (Fechter, 1995; Chen e Fechter, 1999; Chen et al., 2001; Fechter et al., 2002).

3. The oxidation of the neural structures due to the production of free radicals (Fechter et al., 1997; Chen et al., 1999; Rao et al., 2001; Fechter et al., 2002). Still, current knowledge does not allow us to definitively place one of the metabolic mechanisms described as responsible for the potentiating effects of $\mathrm{CO}$ on noise exposure effects.

The phenomenon of potentiating the effects of noise and $\mathrm{CO}$ exposure were analyzed by Young et al. (1987). With a dose of CO at 1200 ppm for 90 minutes and a noise level of $110 \mathrm{dBA}$ for 120 minutes, damage was observed in the region of 40 $\mathrm{kHz}$ when the animals where exposed simultaneously to both agents. The mechanisms implied were not formally identified in this study. The authors relate that it is possible that exposure to sound generates a cochlear vasoconstrictor and that $\mathrm{CO}$ exposure raises the demand of $\mathrm{O}_{2}$.

The aim of Fechter et al. (1988); Fechter (1989)'s research was to confirm that a simultaneous exposure to sound and $\mathrm{CO}$ can cause a potentiation of the effects of noise.
Fechter et al. (1988) wanted to identify the anatomic alterations that had occurred as a consequence of the elevation of the electrophysiological thresholds, so they submitted the rats to an isolated exposure to $105 \mathrm{dBA}$ of noise for 120 minutes. The animals showed cochlear damage concentrated in the most basal region of the cochlea, corresponding to high frequencies. Damage was identified by the absence of the sensory cells observed in an electronic microscope. The two types of sensory cells presented alterations. A larger number of outer hair cells were absent when compared with inner hair cells. With the same exposure to sound they added a simultaneous dose of CO of $1200 \mathrm{ppm}$ for 90 minutes, and a significantly larger number of sensory cells were absent. In a different manner, only the inner hair cells seemed altered. The electrophysiological thresholds presented an alteration in the higher frequencies that corresponded with the location of the lesion in the cochlear portion. They did not observe a lack of sensory cells with the same exposure of only CO.

Fechter (1989) utilized noise exposure levels of $105 \mathrm{dBA}$ for 120 minutes that were presented isolated or simultaneously with CO levels of 250, 500 and 1200 ppm for 90 minutes. The CM and CAP thresholds presented a severe elevation when noise was combined with doses of CO of 500 and 1200 ppm.

The studies by Chen and Fechter (1999); Fechter et al. (2000a); Fechter et al. (2000b), seek to identify the minimum thresholds for the potentiation of $\mathrm{CO}$ on the effects of noise starting with the combined exposure and increasing the doses of $\mathrm{CO}(0,300,500,700,1200$, and $1500 \mathrm{ppm})$ in the presence of noise of 100 and $115 \mathrm{dBA}$ for eight hours. These authors observed significant elevations of CAP and CM thresholds in the presence of $\mathrm{CO}$ in the order of 5 to $10 \mathrm{~dB}$ to the dose of $500 \mathrm{ppm}$, elevating progressively the order of concentration of $1500 \mathrm{ppm}, 30 \mathrm{~dB}$ above the effect of exposure only to sound obtained in the control group. After the concentration of $1200 \mathrm{ppm}$, they observed an alteration in hearing more accentuated in the lower frequencies.

Rao and Fechter (2000) demonstrated that the exposure to $\mathrm{CO}$ potentiate NIHL in a dependent fashion (relative to the exposure to $\mathrm{CO}$ ). The level on which the effect is not observed (NOEL, or noobserved-effect-level) and the lowest level in which an effect is observed (LOEL, lowest-observedeffect- level) were obtained in this study. The authors did a series of calculation for risk analysis, 
by utilizing software of the Environmental Protection Agency, US EPA (MBDS version 1.3). These calculations suggest that the actually permissible limits of exposure to $\mathrm{CO}$ are not sufficiently low to avoid its effects over the auditory system. Exposures to 195-320 ppm of CO are the smallest doses that were observed, with increases of $10 \%$ of NIHL or $5 \mathrm{~dB}$ of the elevation of the respective threshold (Fechter et al., 2000a).

Chen et al. (1999); Rao and Fechter (2000) indicate that even when the noise exposure is reduced by interruptions (long periods of silence), the simultaneous $\mathrm{CO}$ exposure produces permanent alterations in the auditory thresholds. Surprisingly, this data does not validate the relationship between the percentage of time that noise was present (noise duty cycle) and the higher instances of hearing loss. Rao and Fechter (2000) utilized changes of $5 \mathrm{~dB}$ of intensity to manipulate this exposure to noise. The authors utilized a single concentration of CO of $1200 \mathrm{ppm}$ in the presence of an increasing exposure to noise (95dBA for four hours, 100dBA for two hours and 105dBA for one hour). The results demonstrate a non-linear relation between the exposure to sound and the effect of potentiation of $\mathrm{CO}$. With the high doses of exposure to noise (105dBA for one hour), the effect of potentiation of $\mathrm{CO}$ seems limited and the effect of noise seems to predominate. It is at the moderate level of noise (100dBA for two hours), that the effect of potentiation of $\mathrm{CO}$ is more apparent. It has been cited in past studies (Canlon, 1987; Canlon 1988) that as noise exposure increases, structural damages originate in the stereocilia of the hair cells and in the basilar membrane. The exposure to low or moderate noise doses produce, above all, metabolic modifications (Speondlin and Brun, 1973; Speondlin, 1976). The results lead to the suggestion that the effect of potentiation of $\mathrm{CO}$ could be connected to the metabolic modifications, which are initially induced by noise and aggravated with the presence of $\mathrm{CO}$.

These observations raise the question of the appropriateness of the time-intensity paradigm (it limits the time of exposure accordingly to the level of the intensity of noise) adopted by international legislations to determine the exposure limits when agents occurring simultaneously with other toxic agents.

The effects of $\mathrm{CO}$ on the human auditory system

The studies relating the toxicity of $\mathrm{CO}$ exposure on the human auditory system were conducted using acute exposures to $\mathrm{CO}$. In these cases, noise exposure was not a necessary factor for the observed auditory problems.

In 1948, in one of the first studies on the auditory effects of $\mathrm{CO}$, Lumio studied 700 cases of intoxication caused by $\mathrm{CO}$ and observed the prevalence of $78 \%$ of sensory-neural hearing loss.

Garland and Pearce (1967) described four cases of accidental intoxication by $\mathrm{CO}$ accompanied by severe psychiatric and neurological symptoms. Mild and moderate cases of hearing loss were not documented, although an improvement in hearing was observed after 24 hours.

Morris (1969) described the case of a 22 year old that showed a severe bilateral neurosensorial hearing loss caused by intoxication of $\mathrm{CO}$ and after 11 months of observation, his hearing partially recovered.

With the objective of learning the effects of acute $\mathrm{CO}$ intoxication on hearing and balance, Kowaska (1980) studied 50 patients (30 women and 20 men with the average of age of $30 ; 1$ year) they were hospitalized for an intentional or accidental intoxication. The results demonstrated that $42 \%$ of the patients presented a bilateral hearing loss of different degrees, $80 \%$ presented retrocochlear deterioration and $6 \%$ presented deafness. When it comes to balance, $86 \%$ of the patients presented vestibular disorders.

In another study, 78 workers exposed to $\mathrm{CO}$ were evaluated by Kowaska (1981) and 66\% showed some hearing loss and $76.5 \%$ vestibular disorders. According to the author these results confirm the toxic effect of CO.

Choi and Kim (1983) examined the auditory brainstem responses (ABR) of a 36-year-old patient, presented a severe case of intoxication to CO. When admitted to the hospital he was unconscious and had a cerebral anoxia; the concentration of carboxyhemoglobin was of $54 \%$. The results of the ABR demonstrated a normal latency of wave I (1.92 ms). On the contrary, they observed a prolongation of the latency in waves II, III and V (3.20, 4.76 and 9.98 ms respectively) and also a prolongation of the intervals of latency II-III and II-V (1.56 and $3.78 \mathrm{~ms}$ respectively) in the right ear. No observed alteration was noted for interpeak latencies in the left ear.

Thirty two patients were studied with ABR after acute $\mathrm{CO}$ poisoning. The observed alterations were divided in peripheral and central alterations. The peripheral alteration presented a prolongation in the latency of wave I without interpeak latency prolongation (six cases). The central alterations 
presented a prolongation of the latencies for all waves and for the interpeak intervals (two cases). The prevalence of the ABR alterations rose with the duration of the state of unconsciousness for more than 24 hours (Choi, 1985).

Makashima (1988) investigated 15 workers in the coalmines, survivors of an explosion in Japan in 1963. After the CO poisoning these individuals presented a mild neural sensory hearing loss and moderate difficulty in the auditory discrimination (four cases).

Fawcett et al. (1992) revised 220 cases of intoxication of $\mathrm{CO}$. Among these cases, the authors studied 17 forklift operators. All of the patients presented neurological symptoms and/or chronic headaches, receiving treatment in the hyperbaric chamber. The authors also investigated the concentrations of $\mathrm{CO}$ produced by the exhaust of 12 forklifts utilized in different work places. The average concentration of $\mathrm{CO}$ reported in this study was of $30 \mathrm{ppm}$; this dose of $\mathrm{CO}$ constitutes a significant risk of occupational exposure.

Choi (2001) studied 654 cases of patients hospitalized with $\mathrm{CO}$ poisoning between the years 1979 and 1982. The results demonstrated 132 cases presenting systematic complications (two with hearing loss) and 154 presented neurological sequelae.

El Murr et al. (2002) studied a case where a 61year-old patient acquired the extrapyramidal syndrome 15 days after $\mathrm{CO}$ poisoning. The authors also observed a bilateral deafness two months after the appearance of the syndrome. The results of the exams showed ischemic cerebral abnormalities.

Shahbaz Hassan et al. (2003) reported two cases of accidental intoxication of $\mathrm{CO}$ (one was occupational, the other residential) associated with hearing loss. The authors suggest the necessity to consider that the chronic exposure to $\mathrm{CO}$ could be a potential cause of hearing loss.

One of the first studies involving the chronic occupational exposure to $\mathrm{CO}$ and noise was conducted by Lacerda et al. (2005). The authors analyzed a database containing 8647 hearing exams realized by the Quebec National Institute of Public Health between 1983 and 1996. The database was divided in 2 groups: the group I (exposure to noise $=90 \mathrm{dBA}$ and to $\mathrm{CO}$ ) and group II (exposure only to noise $90 \mathrm{dBA}$ ). The results demonstrated significant differences $(\mathrm{p}<0.001)$ in the auditory thresholds of groups I and II, especially for high frequencies $(3,4$ and $6 \mathrm{kHz})$. For group I the effect of the $\mathrm{CO}$ also varied in accordance with the amount of years of noise exposure, especially workers who had been working on the job for more than 20 years.

These findings in humans reinforce the necessity of epidemiological studies, particularly in populations exposed simultaneously to $\mathrm{CO}$ and noise in the workplace (WHO, 1994; Morata, 2002).

\section{Conclusion}

The comprehensive approach taken by Dr. Fechter and his team in the investigation of the toxicity of the asphyxiants in general and of $\mathrm{CO}$ in particular (testing different parameters of exposure and the combination of agents, calculating the dose response, testing hypotheses for the inhibition of the observed effects, among others) offered a valuable contribution for a better comprehension of the mechanisms involved in ototoxicity. They also contributed substantially in the field of occupational health, by bringing up the risks presented by $\mathrm{CO}$, an industrial agent that is also generated by combustion. These findings emphasize that noise might not be the only high-risk agent related to occupational hearing loss and that this effect may be modified by other kinds of exposures.

Our review of the literature indicated that continuous exposure to low doses of $\mathrm{CO}$ is frequent in many work places where the presence of noise is also constant. No clinical study on the potentiating effect of $\mathrm{CO}$ to noise-induced hearing loss was conducted in humans.

Various studies have been published describing auditory effects of acute exposure to $\mathrm{CO}$, even in the absence of excessive noise. Only one study on the auditory effects of the chronic exposure to $\mathrm{CO}$ in the presence of noise in the workplace was found. Studies on this type of combined exposure are highly recommended, for they constitute one of the most important challenges in the area of occupational health.

The necessity of research in this area becomes more evident when one takes in consideration the magnitude of the population that is exposed and yet not monitored and the number of economic sectors where potentially toxic concentration of CO take place, which can contribute to the occurrence of hearing loss in the work place.

The studies reviewed in this article suggest the need of auditory evaluations when workers are exposed to $\mathrm{CO}$ and noise simultaneously and the appropriateness of current exposure limits for combined exposures to these agents. 
Acknowledgements: This study was supported by CAPES, process number BEX 1251/02-3.

The findings and conclusions in this report are those of the author(s) and do not necessarily represent the views of the National Institute for Occupational Safety and Health.

\section{References}

BARIL, M.; BEAUDRY, C. La prévention des accidents causés par le monoxyde de carbone lors de l'utilisation des petits équipements actionnés par des moteurs à combustion interne. IRSST Bilan de Connaissances, Rapport. b-061, p.1-34, 2001.

BAKONYI, S. M. C.; DANNI-OLIVEIRA, I. M. MARTINS, L.C. Poluição atmosférica e doenças respiratórias em crianças na cidade de Curitiba, PR. Rev. Saúde Pública, v. 38 , n. 5, p. 695-700, 2004.
BRASIL. Norma Regulamentadora NR-7 do Ministério do Trabalho. Manuais de Legislação. Atlas Segurança $e$ Medicina do Trabalho. 39. ed. São Paulo: Atlas, 1998.

CANLON, B. Acoustic overstimulation alters the morphology of the tectorial membrane. Hear. Res., v. 30, p. 127-134, 1987

CANLON, B. The effect of acoustic trauma on the tectorial membrane, stereocilia and hearing sensitivity: possible mechanisms underlying damage, recovery and protection. Scand. Audiol., v. 27 (suppl.) p. 1-45, 1988. 
CETESB - Companhia Estadual de Tecnologia e Saneamento Básico. São Paulo, 1991. Disponível em URL: <http://www.conhecimentosgerais.com.br/ecologia/ ecologia-no-brasil-poluicao-do-ar.html> Acesso em: $11 \mathrm{de}$ jul. 2005.

CHEN, G. D.; FECHTER, L. D. Potentiation of octaveband noise induced auditory impairment by carbon monoxide. Hear. Res., v. 132, n. 1-2, p. 149-159, 1999.

CHEN, G. D.; KONG, J.; REINHARD, K.; FECHTER, L. D. NMDA receptor blockage protects against permanent noise-induced hearing loss but not its potentiation by carbon monoxide. Hear. Res., v. 154, n. 1-2, p. 108-115, 2001.

CHEN, G. D.; MC WILLIAMS, M. L.; FECHTER, L. D. Intermittent noise-induced hearing loss and the influence of carbon monoxide. Hear. Res., v. 138, n. 1-2, p. 181-191, 1999.

CHEN, G. D.; MC WILLIAMS, M. L.; FECHTER, L. D. Succinate dehydrogenase (SDH) activity in hair cells: a correlate for permanent threshold elevations. Hear. Res., v. 145 , p. 91-100, 2000.

CHOI, I. S. Brainstem auditory evoked potentials in acute carbon monoxide poisoning. Yonsei Med J., v. 26, n. 1, p. 29-34, 1985.

CHOI, I. S. Carbon monoxide poisoning: systemic manifestations and complications. J. Korean. Med. Sci., v. 16, n. 3 , p. $253-261,2001$.

CHOI, I. S.; KIM, K. W. Brainstem auditory evoked potential in a case of severe carbon monoxide intoxication. Yonsei Med J., v. 24, n. 2, p. 149-152, 1983.

CLOUTIER, F.; GOUDREAU, P. L'exposition au monoxyde de carbone. Médecin du Québec, v. 28, n. 12, p. $65-71,1993$.

CORRIVEAU, M. Étude sur le niveau de pollution par le monoxyde de carbone dans la région de Montréal. 1980. 82 f. Dissertação. (Mestrado em Sciences informartique) Université de Montréal, Montreal, CA.

EH-64. Summary criteria for occupational exposure limits. Documentation of the threshold limit values and biological exposure indices 7 th edition A-D- 1999, HSE Review 1997 D-101.

EL MURR, T.; TOHME, A.; GHAYAD, E. Acute deafness after carbon monoxide poisoning. Case report and review of the literature [in French]. Ann. Med. Interne (Paris), v. 153, n. 3 , p. 206-208, 2002.

FAWCETT, T. A.; MOON, R. E.; FRACICA, P. J.; MEBANE, G. Y.; THEIL, D. R.; PIANTADOSI, C. A. Warehouse workers' headache: carbon monoxide poisoning from propane-fueled forklifts. Journal of Occupational Medicine, v. 34, p. 12-15, 1992.

FECHTER, L. D. A mechanistic basis for interactions between noise and chemical exposure. Archives of Complex Environmental Studes, v 1, n. 1, p. 23-28, 1989.

FECHTER, L. D. Combined effects of noise and chemicals. Occupational Medicine: State of the Art Rewiews, v.10, n. 3, p. 609-621, 1995.

FECHTER, L. D. Overview of animal research on the auditory effects of chemicals. BEST PRACTICES WORKSHOP: COMBINED EFFECTS OF CHEMICALS AND NOISE ON HEARING. 2002, Cincinnati, Ohio, Anais... Cincinnati, 2002.
FECHTER, L. D.; CHEN, G. D.; RAO, D. Characterizing conditions that favour potentialization of noise induced hearing loss by chemical asphyxiants. Noise \& Health, v. 3, n. 9, p. 11-21, 2000a.

FECHTER, L. D.; LIU, Y.; PEARCE, TERRI, A. Cochlear protection from monoxide exposure by free radical blockers in the guinea pig. Toxicol Appl. Pharmacol., v. 142, p. 42-55, 1997.

FECHTER, L. D.; THORNE, P. R.; NUTTALL, A. L. Effects of carbon monoxide on cochlear electrophysiology and blood flow. Hear Res., v. 27, p. 37-45, 1987.

FECHTER, L. D.; YOUNG, J. S.; CARLISLE, L. Potentiation of noise induced threshold shifts and hair cell loss by carbon monoxide. Hear Res., v. 34, p. 39-48, 1988.

FECHTER, L. D.; CHEN, G. D.; RAO, D. Chemical Asphyxiants and Noise. Noise \& Health, v. 4, n. 14, p. 49-61, 2002.

FECHTER, L. D.; CHEN, G. D.; RAO, D.; LARABEE, J. Predicting exposure conditions that facilitate the potentiation of noise-induced hearing loss by carbon monoxide. Toxicol. Sci., v. 58, n. 2, p. 315-323, 2000 b.

FONSECA, J. C. Poluição em garagens fechadas. Vídeos educativos sobre segurança e saúde no trabalho. In: CONGRESSO INTERNACIONAL DE SAÚDE NO TRABALHO, 27., 2003, Foz do Iguaçu, Pr. Anais... Foz de Iguaçu: Fundacentro. Disponível em URL: <http:// www.whoocchealthccs.org/BRA/BRA1/en/news.html> Acesso em: 11 jul. 2005.

FREITAS, C.; BREMNER, S. A.; GOUVEIA, N. Internações e óbitos e sua relação com a poluição atmosférica em São Paulo, 1993 a 1997. Rev. Saúde Pública, v. 38, n. 6, p. 751-757, 2004.

GARLAND, H.; PEARCE, J. Neurological complications of carbon monoxide poisoning. Q. J. Med., v. 36, n. 144, p. 445-455, 1967.

GOUDREAU, P. Évaluation et rédution de l'exposition au monoxyde de carbone des mécaniciens chez les concessionnaires automobiles. Centre de Coordination de la Santé Publique de la Région de Québec. Association Sectorielle. Centre de Documentation Services Automobiles. MO-160312, 1992.

GOUDREAU, P.; PARENT, M.; SOULARD, A. Évaluation et rédution de l'exposition au monoxyde de carbone des mécaniciens chez les concessionnaires automobiles. CLSC Charlevoix, CLSC Haute-ville, CLSC Potneuf. v. 1, p. 1-14, 1995.

HERBERT, R.; SZEINUK, J.; O'BRIEN, S. Occupational health problems of bridge and tunnel officers. Occupational Medicine: State of the Art Rewiews, v. 16, n. 1, p. 51-65, 2001.

HÉTU, R.; PHANEUF, R.; MARIEN, C. Non-acoustic environmental factor influences on occupational hearing impairment: a preliminary discussion paper. Can. Acoust., v. 15 , n. 1, p. 17-31, 1987.

IPCS. International program on chemical safety. Environmental health criteria 213. Carbon monoxide. Inter-organization programme for the sound-management of chemicals. 2. ed. Geneva: WHO, 1999.

IRSST - Institut Robert-Sauvé de Recherche en Santé et Securité au travail. Disponível em URL: <http:// www.irsst.qc.ca>. Acesso em: 25 out. 2003. 
KAMEI, M.; YANAGISAWA, Y. Estimation of CO exposure of road construction workers in tunnel. Ind. Health, v. 35, n. 1, p. 119-125, 1997.

KOSKELA, R. S. Cardiovascular diseases among foundry workers exposed to carbon monoxide. Scand. J. Work Environ Health., v. 20, n. 4, p. 286-293, 1994.

KOSKELA, R. S.; MUTANEN, P.; SORSA, J. A.; KLOCKARS, M. Factors predictive of ischemic disease mortality in foundry workers exposed to carbon monoxide. Am. J. Epidemiol., v. 152, n. 7, p. 628-632, 2000.

KOWASKA, S. State of the organ of hearing and equilibrium in acute carbon monoxide poisoning. Med. Pr., v. 31, n. 1, p. 63-69, 1980.

KOWASKA, S. State of the hearing and equilibrium organs in workers exposed to carbon monoxide. Med. Pr., v. 32, n. 2, p. 145-151, 1981.

LACERDA, A.; LEROUX, T.; GAGNÉ, J. P. The combined effect of noise and carbon monoxide on hearing thresholds of exposed workers. The journal of the Acoustic Society of America, v. 117, n. 4, pt. 2 of 2, p. 2481, 2005.

LALIBERTÉ, M. Exposition environnementale et intoxication au monoxyde de carbone. Bulletin d'information toxicologique. Publication de la direction de la toxicologie humaine. Institut national de santé publique du Québec, v. 17, n. 3, p. 1- 12, 2001.

LARANJEIRA, R.; PILLON, S.; DUNN, J. Environmental tobacco smoke exposure among non-smoking waiters: measurement of expired carbon monoxide levels. Med. J. Rev. Paul. Med., São Paulo, v. 118, n. 4, p. 89-92, 2000.

LAUWERYS, R. R. Toxicologie industrielle et intoxications professionelles. 3.ed. Paris: Masson, 1990. cap, XV, p. 382422.

LEES, P. S. J. Combustion products and other firefighter exposures. Occupational Medicine: State of The Art Reviews, v. 10, n. 4, p. 691-707, 1995.

LIOU, S. H. Occupational-disease profile in Taiwan, Republic-of-China. Industrial Health., v. 32, n. 3, p. 107-118, 1994.

LUMIO, J. S. Clinical findings following chronic carbon monoxide exposure. Acta Otolaryngol. (Stokh), v. 71, (Suppl.) p. 1-112, 1948

MAKASHIMA, K. Otoneurologic manifestations following carbon monoxide poisoning. J. Acoust. Soc. Am., v. 84, p. 38,1988 .

MARTINS, L. C.; LATORRE, M. R. O.; CARDOSO, M. R. A.; GONÇALVES, F. L. T.; SALDIVA. P. H. N.; BRAGA, A. L. F. Poluição atmosférica e atendimentos por pneumonia e gripe em São Paulo, Brasil. Revista de Saúde Pública, v. 36, n. 1, p. 88-94, 2002.

MELIUS, J. Occupational health for firefighters. Occup. Med., v. 16, n. 1, p. 101-108, 2001

MILLETTE, J. Monoxide de carbone, dans la mire de la santé du travail et de la santé publique. Prévention au Travail, v. 15 , n. 2, p. 23-25, 1992.

MORATA, T. C. Interaction between noise and asphyxiants: a concern for toxicology and occupational health. Toxicol Sci., v. 66, p. 1-3, 2002.
MORRIS, T. M. O. Deafness following acute carbon monoxide poisoning. J. Laryngol. Otol., v. 83, p. 1219-1225, 1969.

MORLEY, J. C.; SEITZ, T.; TUBBS, R. Carbon monoxide and noise exposure at a monster truch and motocross show. Appl. Occup. Environ Hyg., v. 14, n. 10, p. 645-655, 1999.

NIOSH. National institute for occupational safety and health. Occupational health guidelines for carbon monoxide. Occupational health guidelines for chenical harzards, v. 1, p. 1-4, 1981.

NIOSH. National institute for occupational safety and health. 2004. Pocket guide to chemical hazards (NPG). Publication $\mathrm{n}^{\circ}$ 97-140. Disponível em URL: <http:// www.cdc.gov/niosh/npg/npg.html>. Acesso em 30 out. 2005.

OCCUPATIONAL SAFETY AND HEALTH ADMINISTRATION, 1991. Final regulatory analysis of the hearing conservation amendement. Washington, DC:U.S. Department labor, occupational safety and health admistration (OSHA). Fed. Reg. 46:4076.

PENNEY, D. G.; HOWLEY, J. W. Is there a connection between carbon monoxide exposure and hypertension? Environ Health Perspectives, v. 95, p. 191-198, 1991

PENNEY, D. G. Chronic carbon monoxide poisoning. In: PENNEY, D. G. Carbon monoxide toxicity. Boca Raton, Florida: CRC Press, 2000. cap. 18, p. 394-420.

RAO, D. B.; FECHTER, L. D. Increased noise severity limits potentiation of noise induced hearing loss by carbon monoxide. Hear Res., v. 150, n. 1-2, p. 206-214, 2000.

RAO, D. B.; MOORE, D. R.; REINKE, L. A.; FECHTER, L. D. Free radical generation in the cochlea during combined exposure to noise and carbon monoxide: an electrophysiological and an EPR study. Exposure Research, v. 161, p. $113-122,2001$.

SILVA, V. L. Environmental tobacco smoke exposure among non-smoking waiters: measurement of expired carbon monoxide levels. São Paulo Medical Journal/ Revista Paulista de Medicina, v. 118, n. 4, p. 81-82, 2000.

SHAHBAZ HASSAN, M.; RAY, J.; WILSON, F. Carbon monoxide poisoning and sensorineural hearing loss. $J$. Laryngol. Otol., v. 117, n. 2, p. 134-137, 2003.

SCHNEIDER, S. P. Noise and ototoxic chemicals in construction. BEST PRACTICES WORKSHOP: COMBINED EFFECTS OF CHENICALS AND NOISE ON HEARING. Cincinnati, Ohio. Anaiss... Cincinnati, 2002,

SPOENDLIN, H.; BRUN, J. P. Relation of structural damage to time and intensity in acoustic trauma. Acta OtoLaryngologica, v. 208, p. 220-226, 1993.

SPOENDLIN, H. Anatomical changes following various noise exposures. In: HENDERSON, D.; HAMERNICK, R. P.; DOSANJH, D. S.; MILLS, J. H. Effects of noise on hearing. New York: Raven Press, 1976. p. 69-90.

STEENLAND, K. Epidemiology of occupational and coronary heart disease: research agenda. Am. J. Ind. Med., v. 30, n. 4, p. 495-499, 1996.

TAWACKOLI, W.; CHEN, G. D.; FECHTER, L. D. Disruption of cochlear potentials by chemical asphyxiants Cyanide and carbon monoxide. Neurotoxicol Teratol., v. 23, p. $157-165,2001$. 
TREITMAN, R. D.; BURGESS, W. A.; GOLD, A. Air contaminants encountered by firefighters. Am. Ind. Hyg. Assoc. J., v. 41, p. 796-802, 1980.

YOUNG. J. S.; UPCHURCH, M. B.; KAUFMAN, M. J.; FECHTER, L. D. Carbon monoxide exposure potentiates high-frequency auditory threshold shifts induced by noise. Hear. Res., v. 26, n. 1, p. 37-43, 1987.

WALKER, S. M.; ACKLAND, T. R.; DAWSON, B. The combined effect of heat and carbon monoxide on the performance of motorsport athletes. Comparative biochemistry e physiology. Part A. Molecul. Integ. Physiol., v. 4, n. 128 p. 709-718, 2001.

WICKRAMATILLAKE, H. D.; GUN, R. T.; RYAN, P. Carbon monoxide exposures. Austr New Zealand J. Pub. Health, v. 22, n. 3, p. 389-393, 1998. Suppl.

WORLD HEALTH ORGANIZATION - WHO. Carbon monoxide. Enviromental health criteria 13, Geneva: WHO, 1979.

WORLD HEALTH ORGANIZATION - WHO International workshop: setting priorities in environmental epidemiology- report on a Word Health Organization Meeting. Arch Environ Health, v. 49, n. 4, p. 239-245, 1994. 